\title{
The English adverbial of time vs. the vietnamese range topic of time
}

\author{
Thanh Minh To \\ Faculty of English Linguistics and Literature, University of Social Sciences and Humanities, Vietnam National University - Ho Chi Minh \\ City, Vietnam
}

\section{Email address:}

minhthanhto@gmail.com,minhthanhto@hcmussh.edu.vn

\section{To cite this article:}

Thanh Minh To. The English Adverbial of Time vs. the Vietnamese Range Topic of Time. International Journal of Language and Linguistics. Vol. 2, No. 6, 2014, pp. 348-355. doi: 10.11648/j.ijl1.20140206.12

\begin{abstract}
Differences between the function of the adverbial of Time and that of the range topic of Time may lead Vietnamese language users to the risk of mistakenly translating the English clause with the adverbial of Time. The recommended translation of the English commercial note "Have you had a Coke today?" is "Hôm nay bạn đã uống Coca-Cola chưa?", in which the adverbial of Time at the end of the English clause should be converted into the range topic of Time at the beginning of its Vietnamese equivalent, to meet the requirement of the Topic-Comment structure of the Vietnamese clause. In the mistakenly used version "Bạn đã uống Coca-Cola hôm nay chưa?" hôm nay can also be considered as an adjectival to be the post-nominal modifier of Coca-Cola, resulting in a case of structural ambiguity that should always be avoided. The research reported in this paper was carried on the basis of the theory of the Topic-Comment structure applied by Hao X. Cao (1991) to Vietnamese as a natural language to search for (i) dissimilarity with regard to word order when translating into Vietnamese the English clause with one or more adverbials including the adverbial of Time; (ii) possible cases when native speakers apply the fronting of the adverbial of Time in the English clause, like "Tonight I'll call you." instead of "I'll call you tonight." and (iii) any potential change in the meaning they would like to convey with such fronting.
\end{abstract}

Keywords: Adverbial, Range Topic, Topic-Comment Structure, Fronting (Movement), Point of Time, Extent in Time, Principle of End-Weight

\section{Introduction}

The commercial note "Have you had a Coke today?" has been translated from English to Vietnamese and exposed to the public in Vietnam recently as "Bạn đã uống Coca-Cola hôm nay chưa?" By maintaining the word order in English, the above-mentioned translated version is structurally ambiguous because hôm nay can also be considered as an adjectival to be the post-nominal modifier of Coca-Cola. In order to avoid such structural ambiguity, the Vietnamese version "Hôm nay bạn đã uống Coca-Cola chưa?" is recommended. This realization indicates that the adverbial of Time (abbreviated to $A$ of Time) at the end of the English clause in question should be converted into the range topic of Time at the beginning of its Vietnamese equivalent. The above-mentioned example shows that differences in the role of the $A$ of Time and that of the range topic of Time may lead Vietnamese language users to the risk of mistakenly translating the English clause with the $A$ of Time. This is definitely the focus of this paper.

\section{Aims and Theoretical Background of Research}

\subsection{Theoretical Background of Research}

According to Stageberg and Oaks (2000: 249-270) [1], the four positional classes in English are nominals, verbals, adjectivals and adverbials. Adverbials are the word groups as well as the single words that occupy the adverb positions and perform the adverb functions. Common adverbial positions are:

Initial position:

Really, you should know better.

Now it is time to go.

Medial position:

Mary in her own way was a darling.

He is always/ at any event happy. 
She would seldom make effort.

Final position:

He drove recklessly/ with abandon.

She is outside.

Hoskins will play football tomorrow.

According to Hao X. Cao (1991) [2], the prominent structure of the Vietnamese clause is not the SubjectPredicate structure but the Topic-Comment structure. "Topic" is a cover term which includes the Topic (called "Chủ đề" in Vietnamese), - "the starting-point for the message" (Halliday, 1994, p. 38) [3], and the Range Topic (called "Khung đề" in Vietnamese) - "the first part of the clause clearly indicates the conditions constituting the frame of circumstance, time and space in which what is stated in the second part of the clause, the Comment, holds true" (Hao X. Cao, 1991, p. 82) [2]. Below are example given by Cao Xuân Hạo, illustrating the range topic of Time; and the researcher tried to translate them into English (Thanh M. To, 2011: 267) [8]:

Sang năm THÌ sống được đấy.

(We can manage to earn our bread next year.)

Sang năm MÀ ở Vinh gạo mỗi tạ giá 200 ngàn LÀ tối đa, ở đây hàng tuần tụi tôi chủ nhật nào cũng mỗi người một xe tải làm mấy chuyến THİ cũng sống được đấy.

(Next year if rice costs a maximum of 200 thousand a quintal in Vinh and if we do a few times every Sunday, each driving a truck, then we can manage to earn our bread.)

The research reported in this paper was done on the basis of the theory of the Topic-Comment structure applied by Hao X. Cao (1991) [2] to Vietnamese as a natural language. Up to now there have been a number of studies done in Vietnam and based on the above-mentioned theory of the TopicComment structure in the Vietnamese language; however, nothing has been done to compare and contrast the $A$ of Time in English and the range topic of Time in Vietnamese.

\subsection{Aims of Research}

The research reported in this paper aims at looking for (i) dissimilarity with regard to word order when translating into Vietnamese the English clause with one or more adverbials including the $A$ of Time, (ii) possible cases when native speakers apply the "fronting" (Dyvik, 1984, p. 10) [4] of the A of Time in the English clause, and (iii) any potential change in the meaning they would like to convey with such fronting.

\section{Scope and Procedure of Research}

In order to achieve the above-mentioned aims, the research was done under the following procedure:

Firstly came the search for examples of the A of Time either standing as the only modifier or occurring together with another adverbial, of the same or different type, at the end of the English clause, which in turn either exists as a simple sentence or is embedded as part of a complex sentence of one type or another.

Secondly, an American colleague of the researcher, who is a volunteer visiting teacher at her university in Vietnam, proofread with great generosity all the examples selected to guarantee that they are those that native speakers of English would normally say.

Then, the researcher tried her best to translate the selected examples into Vietnamese, grouping them into a number of categories as presented in the paper.

Finally, up to ten native speakers were requested to read for double check that the paper's selected examples are normal to them and answer one or more of the following questions:

- When applying the fronting of the $A$ of Time as in (29)a or (34)a in the paper, do native speakers of English mean something different? Respectively, how do (1)a and (35)a differ in meaning from (29)a and (34)a?

- How different is the meaning conveyed by (35)a from that of (36)a in the paper?

The research started with the English clause containing the A of Time which occurs in the form of a simple sentence and part of a complex sentence; it then shifted to observe in a number of dialogues utterances in tokens of simple sentences, not utterances of non-sentences like short phrases or single words. This was done following the view by Hurford, Heasley and Smith (2007, pp. 16-17) [5] that sentences are "ideal"" whereas utterances are "particular"2.

Also, within the scope of the research is the $A$ of Time in the form of (i) a close-class adverb like tonight, sometimes,...; (ii) an adverb phrase basically with close-class adverb as head like just now, right now,...; (iii) a noun phrase (abbreviated to NP) like last time, every day,...; (iv) a prepositional phrase (abbreviated to PP) like in two days, from tomorrow,...; thus excluding all of other realizations (Quirk et al, 1985, pp. 489, 592) [6].

\section{Result of Research}

Presented in this paper ${ }^{3}$ is the result of the research in the form of four main sections: the first two present the obligatory or optional fronting movement of the English $A$ of Time during the process of English-Vietnamese translation; the third covers some tips to translate the English clause with an $A$ of Time; the last section reveals some native speakers' perceptions through feeling on possible change of meaning when the fronting of the English $A$ of Time is applied.

\footnotetext{
1"A sentence can be thought of as the IDEAL string of words behind various realizations in utterances and inscriptions." Hurford, Heasley and Smith (2007, p. 17) [5]

2“An utterance is the USE by a particular speaker, on a particular occasion, of a piece of language, such as a sequence of sentences, or a single phrase, or even a single word." Hurford, Heasley and Smith (2007, p. 16) [5]

${ }^{3}$ Conventions applied in this paper are:

Original English clauses selected as illustration are numbered, marked $a$ and followed by the Vietnamese translated version(s), marked either $b$, or $b$ and $c$, etc.; The lexical items in round brackets, like "(lại)" in (3)b-c, may or may not be verbalized while those in square brackets, like "[what's on TV tonight]" in (10)a, are embedded clauses;

The three symbols " $\rho$ ", “*”, and "?" respectively stand for "or", "unaccepted" and "possibly accepted."

For clarification in the examples marked with numbers and given as illustrations in this paper, both the adverbial of Time and the range topic of Time are in italic.
} 


\subsection{Cases of Obligatory Fronting}

During the process of English-Vietnamese translation, the $A$ of Time is obligatorily fronted usually from the end of an English clause to the beginning of its Vietnamese equivalent to perform a new function there: the range topic of Time. The rule is applied under certain circumstances:

\subsubsection{The English Clause in the Form of a Simple Sentence}

4.1.1.1. With an A of Time at the end of the English clause:

(1)a. I'll call you tonight.

b. Tối nay tôi sẽ gọi cho chị.

c.?Tôi sẽ gọi cho chị tối nay.

(2)a. What's on TV tonight?

b. Tối nay TV có gì?

c.?TV có gì tối nay?

(3)a. Why were you absent last time?

b. Tại sao lần trước anh (lại) vắng mặt?

c.?Tại sao anh (lại) vắng mặt lần trước?

(4)a. I'll pay you in two days.

b. Hai ngày nũa (thì) tôi sẽ trả tiền cho chị.

c.?Tôi sẽ trả tiền cho chị hai ngày nũa.

Though it is not quite unaccepted, (1-4)c sound more or less unnatural to native speakers of Vietnamese. Thus, (1-4)b are much preferred. At the end of a clause, the English $A$ of Time appears in the form of an NP, as in (1-3)a, or a PP, as in (4)a, whereas the Vietnamese $A$ of Time should be in the form of a PP, more strictly obeying "the principle of end-weight: the tendency for long and complex elements to be placed towards the end of a clause" (Biber et al, 1999, p. 898) [7], resulting in (1-4)d:

(1)d. Tôi sẽ gọi cho chị vào tối hôm nay.

(2)d. TV có gì trong chuơng trình của tối hôm nay?

(3)d. Tại sao anh (lại) vắng mặt trong lần họp trước?

(4)d. Tôi sẽ trả tiền cho chị trong hai ngày nũa.

Like (1-4)b, (5-6)b are undoubtedly preferred translated versions because they clearly follow the Topic-Comment structure of the Vietnamese clause (Cao Xuân Hạo, 1991, p. $23,28)[1]$ the range topic of Time of which is not in the form of a PP, but in the form of an NP, to obey again the principle of end-weight: the tendency for short and simple elements to be placed towards the beginning of a clause. To native speakers of Vietnamese, (5-6)c sound unnatural: they do not follow the above-mentioned Topic-Comment structure.

(5)a. I had no driver's license/ did not have a driver's license before.

b. Trước đây tôi không có bằng lái xe.

c. ${ }^{*}$ Tôi không có bằng lái xe trước đây. ${ }^{4}$

$\mathrm{d}$. Tôi không có bằng lái xe trong thời gian trước đây.

(6)a. Why did Tom ignore us just now?

b. Tại sao vìa rồi/ mói đây Tom (lại) phớt lờ bọn mình?

c. *Tại sao Tom (lại) phớt lờ bọn mình vìa rồi/ mói đây?

d. *Tại sao Tom (lại) phớt lờ bọn mình trong vì̀a rồi/

${ }^{4}$ Truớc đây, meaning "before", can also be considered as an adjectival to be the post-nominal modifier of the NP bằng lái xe, meaning "driver's license." Another reason why (5)c is not recommended is that it may lead to structural ambiguity. vào mói đây?

Since neither vùa rồi nor mói đây is an NP, no PP is formed as the result of the insertion of trong or vào; consequently, (6)d is not as grammatical as (5)d.

4.1.1.2. With an $A$ of Time included somewhere rather than at the end of the English clause:

(7)a. I now pronounce you man and wife.

b. Bây giờ cha tuyên bố hai con là vợ chồng.

c.?Cha bây giờ tuyên bố hai con là vợ chồng.

d. *Cha tuyên bố hai con là vợ chồng bây giò̀.

e. * Cha tuyên bố hai con là vợ chồng trong bây giơ/ vào bây giò.

The preferred translated version of the vicar's declaration at the wedding ceremony held in a church is no doubt (7)b. With correct pauses applied in speech, though there is no explicit mark for the pauses in writing, (7)c might also be accepted; it is obvious that the insertion of a time expression in the form of an NP somewhere within the Vietnamese clause rather than in the initial position is far from common. Again, (7)d is unaccepted, for at the end of a clause the Vietnamese $A$ of Time can hardly take the form of an NP or a pronoun like bây giò; instead, it should be in the form of a PP to obey the principle of end-weight, as already mentioned in 4.1.1.1. And (7)e is incorrect because of the same reason as (6)d: since bây giờ is not an NP, no PP is formed as the result of the insertion of trong or vào.

4.1.1.3. With a sequence of two adverbials of Time at the end of the English clause:

(8)a. John had thirteen friends to tea on his birthday yesterday.

b. *Hôm qua có 13 bạn đến dự tiệc vào ngày sinh nhật của John.

c. *Vào ngày sinh nhật của John có 13 bạn đến dự tiệc hôm qua.

d.?Hôm qua vào ngày sinh nhật của John có 13 bạn đến dự tiệc.

e. Vào ngày sinh nhật của John hôm qua có 13 bạn đến dự tiệc.

f. *Có 13 bạn đến dự tiệc vào ngày sinh nhật của John hôm qua.

g. *Có 13 bạn đến dự tiệc hôm qua vào ngày sinh nhật của John.

h. Hôm qua có 13 bạn đến dự tiệc sinh nhật của John.

Even when it has the range topic of Time in the form of an NP and the remaining $A$ of Time in the form of a PP, which is long and complicated enough to satisfy the principle of endweight, (8)b is unaccepted, like (8)c, because the cooccurrence of the range topic of Time at the beginning and an $A$ of Time at the end of the Vietnamese clause is impossible. This recommends the act of translating the remaining $A$ of Time into the post-nominal adjectival modifier of tiẹc, the noun meaning "tea" - a meal in the early evening, in (8)h. This act makes (8)h the only approved translated version and helps to indicate the fact that the sequence of two time expressions is not highly appreciated at both the beginning and the end of the Vietnamese clause, as shown in (8)e-g. Possibly accepted is (8)d, in which the range topic of Time in 
the form of an NP precedes the range topic of Time in the form of a PP: at least the "double Topic" (Dyvik, 1984, p. 3) [4] avoiding the violation of the principle of end-weight.

4.1.1.4. With a final sequence of an $A$ of Time followed by an adverbial of another type, of Condition (abbreviated to A of Condition), for example:

(9)a. You look lovely today in your new dress.

b. Hôm nay cô trông rất xinh trong bộ váy áo mới này. c. *Trong bộ váy áo mới này cô trông rất xinh hôm nay. d.?Hôm nay trong bộ váy áo mới này cô trông rất xinh. e. *Trong bộ váy áo mới này hôm nay cô trông rất xinh. f. *Cô trông rất xinh hôm nay trong bộ váy áo mới này. g. *Cô trông rất xinh trong bộ váy áo mới này hôm nay.

Unlike (8)b, (9)b is fine because the co-occurrence of the range topic of Time at the beginning and an A of Condition at the end of the Vietnamese clause is approved. The Double Topic (called "Đề kép" in Vietnamese) of Time-plusCondition in (9)d makes it possibly accepted, like the above (8)d. Not accepted is the opposite of Condition-plus-Time in (9)e, which is worsened by the flouting of the principle of end-weight. This may explain why (9)c is also unapproved. Still again, the final sequence of two adverbials, one of Time and the other of another type, is not quite accepted in the Vietnamese clause, as shown in (9)f-g.

4.1.1.5. With an $A$ of Time at the end of the English clause realized as part of a dialogue:

The translated $A$ of Time is fronted even in utterances as part of the three following dialogues; the first two illustrate the range topic of Time, which can be marked by the word thi, while the last one exemplifies the Topic being marked by the word là:

Dialogue 1:

Minister of Education: I resign.

(Bộ trưởng Bộ Giáo dục: Tôi xin từ chức.)

Prime Minister: You'll be free from tomorrow.

(Thủ tướng: Kể tù ngày mai (thì) anh/ chị được tự do.)

Dialogue 2:

Wife: Can you help me set the table?

(Vợ: Anh giúp em bày bàn ăn được không?)

Husband: I'm busy right now.

(Chồng: Ngay bây giờ (thì) anh bận.)

Dialogue 3:

George: How about dinner out?

(George: Tối nay mình đi ăn tiệm chứ?)

Beth: Thanks, but my essay is due tomorrow morning.

(Beth: Xin cám ơn, nhưng sáng mai là đến hạn nộp bài luận của em.)

\subsubsection{The English clause as Part of a Complex Sentence}

The above-mentioned explanations hold true here when the English clause is embedded in a complex sentence as it occurs as a simple sentence in 4.1.1.

4.1.2.1. With an $A$ of Time at the end of the English embedded clause:

(10)a. Can you tell me [what's on TV tonight]?

b. Cho mình biết [tối nay TV có gì].

c. Cho mình biết ?[TV có gì tối nay]. d. Cho mình biết [TV có gì trong chương trình của tối hôm nay].

(11)a. I wonder [why Tom ignored us just now].

b. Tôi tự hỏi [tại sao vì̀a rồil mới đây Tom (lại) phớt lờ bọn mình].

c. Tôi tự hỏi * [tại sao Tom (lại) phớt lờ bọn mình vìa rồi/ mói đây].

d. Tôi tự hỏi *[tại sao Tom (lại) phớt lờ bọn mình trong vì̀a rồi/ vào mói đây].

4.1.2.2. With a sequence of two adverbials of Time at the end of the English embedded clause:

(12)a. His mother said [that John had thirteen friends to tea on his birthday yesterday].

b. Mẹ của John nói *[rằng hôm qua có 13 bạn đến dự tiệc vào ngày sinh nhật của John].

c. Mẹ của John nói *[rằng vào ngày sinh nhật của John có 13 bạn đến dự tiệc hôm qua].

d. Mẹ của John nói ?[rằng hôm qua vào ngày sinh nhật của John có 13 bạn đến dự tiệc].

e. Mẹ của John nói *[rằng vào ngày sinh nhật của John hôm qua có 13 bạn đến dự tiệc].

f. Mẹ của John nói *[rằng có 13 bạn đến dự tiệc vào ngày sinh nhật của John hôm qua].

g. Mẹ của John nói *[rằng có 13 bạn đến dự tiệc hôm qua vào ngày sinh nhật của John].

h. Mẹ của John nói [rằng hôm qua có 13 bạn đến dự tiệc sinh nhật của John].

\subsection{Cases of Optional Fronting}

During the process of English-Vietnamese translation, the A of Time is optionally fronted from the end of an English clause to the beginning of its Vietnamese equivalent to perform a new function there - the range topic of Time. The rule is applied under certain circumstances.

4.2.1. When the English clause ends with a sequence of an adverbial of Space (abbreviated to A of Space) before an $A$ of Time:

(13)a. I heard that on the radio yesterday, too.

b. Anh cũng nghe điều đó trên radio hôm qua rồi.

c.?Anh cũng nghe điều đó hôm qua trên radio rồi.

d. Hôm qua anh cũng nghe điều đó trên radio rồi.

e. *Trên radio anh cũng nghe điều đó hôm qua rồi.

f.?Hôm qua trên radio anh cũng nghe điều đó rồi.

g. *Trên radio hôm qua anh cũng nghe điều đó rồi.

(14)a. Did you go to the movies last night?

b. Mày đi xem phim đêm hôm qua hả? ${ }^{5}$

c. *Mày đi đêm hôm qua xem phim hả?

d. Đêm hôm qua mày đi xem phim hả?

e.?Đến rạp chiếu phim mày đi đêm hôm qua hả?

f. ĐĐêm hôm qua đến rạp chiếu phim mày đi hả?

g. *Đến rạp chiếu phim đêm hôm qua mày đi hả?

\footnotetext{
${ }^{5}$ The word-by-word translated version (14)b' does not convey the real meaning of (14)a, failing to make native speakers of Vietnamese understand in the same way as native speakers of English do:

(14)b'. Mày đi đến rạp chiếu phim đêm hôm qua hả?

Did you go to the building where films are shown last night?
} 
At the end of a clause, the sequence of an A of Time after an adverbial of another type, especially an A of Space, is quite common in both English and Vietnamese, preventing (13-14)b from being rare; the sequence of a time expression before another adverbial is more marked, as proved by the less common (13)c and the unaccepted (14)c. Recommended to be the first version selected for translation are (13-14)d, with the range topic of Time and a final adverbial of another type; the opposite (13-14)e sound really strange because the order of the range topic of Space and a final $A$ of Time is rare in the Vietnamese clause. The Double Topic of Time-plusSpace makes (13)f less rare while that of Space-plus-Time makes $(13-14) g$ too unnatural to be approved. While the degree of acceptability is not always easy to determine in comparing (13)f with (14)f, the feeling of naturalness can be strengthened if the $A$ of Time in (13)a-b, for example, turns to be a bit longer and more complicated in structure to meet the principle of end-weight, resulting in (15)a-b:

(15)a. I heard that on the radio yesterday morning, too.

b. Anh cũng nghe điều đó trên radio vào sáng ngày hôm qua rồi.

4.2.2. When the English clause which ends with a sequence of an A of Space before an $A$ of Time, either finite as in (16)a or non-finite as in (17)a, is embedded in a complex sentence:

(16)a. I wonder [why Tom ignored us on the street just now].

b. Tôi tự hỏi ?[tại sao Tom đã phớt lờ bọn mình ngoài phố vùa rồi].

c. Tôi tự hỏi *[tại sao Tom đã phớt lờ bọn mình vì̀a rồi ngoài phố].

d. Tôi tự hỏi [tại sao vùa rồi Tom đã phớt lờ bọn mình ngoài phố].

e. Tôi tự hỏi *[tại sao ngoài phố Tom đã phớt lờ bọn mình vì̀a rồi].

f. Tôi tự hỏi ?[tại sao vì̀a rồi ngoài phố Tom đã phớt lờ bọn mình].

e. Tôi tự hỏi *[tại sao ngoài phố vìa rồi Tom đã phớt lờ bọn mình].

(17)a. He regrets [losing his temper at work this morning].

b. Ông hối tiếc [đã nổi cáu ở chỗ làm sáng nay].

c. Ông hối tiếc ?[đã nổi cáu sáng nay ở chỗ làm].

d. Ông hối tiếc [sáng nay đã nổi cáu ở chỗ làm].

e. Ông hối tiếc *[ở chỗ làm đã nổi cáu sáng nay].

f. Ông hối tiếc *[sáng nay ở chỗ làm đã nổi cáu].

g. Ông hối tiếc * [ở chỗ làm sáng nay đã nổi cáu].

The above explanations hold basically true here when the English clause is embedded in a complex sentence as well as when it occurs as a simple sentence in 4.2.1. However, that (17)b is quite accepted considers the fronting of the $A$ of Time in (17)d as optional; that (16)b is possibly accepted casts doubt on the obligatory fronting in (16)d. It is recommended to translate the embedded clause from non-finite in English to a finite form in Vietnamese, i.e. the subject ong should be overt:

(17)d'. Ông hối tiếc [là/ rằng sáng nay ông đã nổi cáu ở chỗ làm]. f'. Ông hối tiếc [là/ rằng sáng nay ở chỗ làm ông đã nổi cáu].

4.2.3. When the English clause embodies a modal expression together with a final sequence of an A of Space followed by an $A$ of Time:

(18)a. I am supposed to go to Hanoi this weekend.

b. Lẽ ra cuối tuần này tôi phải đi Hà Nội.

c.?Lẽ ra tôi phải đi Hà Nội cuối tuần này.

d. Lẽ ra tôi phải đi Hà Nội vào cuối tuần này.

There are two acts of fronting during the process of translation: the $A$ of Time becomes the range topic of Time while the modal expression am supposed to turns into a combination of the range topic of Modality le $r a$ and the modal verb phái, resulting in the Double Topic typical of the Vietnamese clause in (18)b. It is the sequence of an $A$ of Space before an $A$ of Time that makes (18)a common in English and (18)c accepted in Vietnamese. At the end of the Vietnamese clause should be the $A$ of Time in the form of a $\mathrm{PP}$, as in (18)d, to meet the principle of end-weight.

4.2.4. When the English clause ends with a sequence of two adverbials of Time, "the superordinate adjunct (the one denoting the more extended period)" (Quirk et al, 1985, p. 533) [6] optionally being fronted:

(19)a. We'll meet tonight after the show.

b. Mình sẽ gặp nhau đêm nay, sau buổi biểu diê̂n.

c. Đêm nay mình sẽ gặp nhau, sau buổi biểu diê̂n.

This holds true even when there is an A of Space before two adverbials of Time:

(20)a. I was in New York last year before the first snow fell.

b. Tôi ở New York hồi năm ngoái, trước khi nhũng bông tuyết đầu tiên rơi.

c. Năm ngoái tôi ở New York, trước khi nhũng bông tuyết đầu tiên rơi.

4.2.5. When the English embedded clause is finite and has its adverbial of Sequence of Events (abbreviated to A of Sequence) (Thanh M. To, 2011, p. 262) [8] fronted, i.e. converted into the range topic of Time, while the $A$ of Time kept in the final position to meet the principle of end-weight, there exists a change in form during the process of translation from an NP, like last night in (21)a, quoted from Cook (1989, p. 7) [9], to a PP, like vào đêm hôm qua in (21)b-c. That (21)c may also be accepted shows how flexible the semantosyntactic function of sau đó is in the Vietnamese clause: the range topic of Time in (21)b or the A of Sequence in (21)c:

(21)a. We thought it was right to come to a decision [when I next met them last night].

b. Chúng tôi nghĩ đã đến lúc đưa ra quyết định [khi sau đó tôi gặp họ vào đêm hôm qua].

c. Chúng tôi nghĩ đã đến lúc đưa ra quyết định ?[khi tôi sau đó gặp họ vào đêm hôm qua].

4.2.6. When the English clause has two Vietnamese equivalent versions the range topic of Time of the first can be marked by the word thi, like $(22-23) b$, whereas the alternative expression exists without thi, like (22-23)c:

(22)a. I can't answer your question right now.

b. Ngay bây giờ (thì) tôi không thể trả lời câu hỏi của 
chị được.

c. Tôi không thể trả lời câu hỏi của chị ngay bây giờ được.

(23)a. What do you usually do in your free time?

b. Lúc rảnh rỗi/ Khi rảnh rỗi/ Những khi rảnh rỗi/

Nhũng lúc rảnh rỗi (thì) anh thường làm gì?

c. Anh thường làm gì lúc rảnh rỗi/ khi rảnh rỗi/nhũng

khi rảnh rỗi/ nhũng lúc rảnh rỗi/vào thời gian rảnh?

Such alternative use can also be observed in the following dialogues:

Dialogue 4:

Wife: Who is picking up the children today?

(Vợ: Hôm nay (thì) ai sẽ đón con?)

Husband: I've got a meeting at 3.30.

(Chồng: Lúc 3 giờ ruỡi (thì) anh có một cuộc họp./ Anh có một cuộc họp vào lúc 3 giờ ruõ̃i.)

Dialogue 5:

Tourist: Do you expect a lot of rain this month?

(Du khách: Tháng này (thì) trời có nhiều mưa không?)

Tour guide: It hardly ever rains in March.

(Hướng dẫn viên: Tháng $b a$ (thì) trời hầu như không mưa./

Trời hầu như không mưa vào tháng $b a$.)

The above-mentioned explanations hold true here even when the English clause occurs not as a simple sentence but as part of a complex sentence:

(24)a. I'm afraid [that I can't answer your question right now].

b. Tôi $\mathrm{e}$ [rằng ngay bây giờ (thì) tôi không thể trả lời câu hỏi của chị được].

c. Tôi $\mathrm{e}$ [rằng tôi không thể trả lời câu hỏi của chị ngay bây giờ được].

4.2.7. When the English embedded clause is non-finite and has two Vietnamese equivalents which can both be marked by the word là, as in $(25) \mathrm{b}-\mathrm{c}$ :

(25)a. I regret [drinking so much last night].

b. Tôi hối tiếc [(là) đêm hôm qua đã uống quá nhiều].

c. Tôi hối tiếc [(là) đã uống quá nhiều vào đêm hôm qua].

4.2.8. When the English clause has its $A$ of Time referring to Extent in Time, not Point of Time ${ }^{6}$ (Tô Minh Thanh, 2011, p. 49-50, 105-106) [8]:

(26)a. John's sister has been in the hospital for a week.

b. Chị/ Em gái của John đã nằm bệnh viện một tuần rồi.

c. *Một tuần rồi (thì) chị/ em gái của John đã nằm bệnh viện.

(27)a. They waited until the last minute.

b. Họ đã đợi đến phút cuối cùng.

c. *Đến phút cuối cùng (thì) họ đã đợi.

(28)a. Can I talk to you for a while?

b. Tôi nói chuyện với chị một lát được không?

c. *Một lát (thì) tôi nói chuyện với chị được không?

In summary, what has been presented in the first two

${ }^{6}$ Respectively, Point of Time (called Thờ điểm in Vietnamese) and Extent in Time (called Thờ đoạn in Vietnamese) are referred to as "Time position" and "Time duration" by Quirk et al (1985, p. 487) [6]. sections helps to prove that:

- As for both English and Vietnamese, the final sequence of an A of Time after an adverbial of another type, especially an A of Space, is quite common; also common is the $A$ of Time of an English clause being fronted to function as the range topic of Time in its translated version.

- As for the Vietnamese clause exclusively, (i) the range topic of Time is undoubtedly prominent, (ii) the Double Topic is more common than the dual final adverbials, (iii) Time-plus-Space is approved in the Double Topic while Space-plus-Time is more accepted in the dual final adverbial, and (iv) the range topic of Time plus a final adverbial of another type, especially of Space, not the range topic of Space plus a final $A$ of Time, is recommended.

- The above-mentioned assertions hold basically true even when the English clause and its translated version occur not only as a simple sentence but also as part of a complex sentence.

\subsection{Tips for Translating the English A of Time}

The analysis in the paper's first two sections supports the following tips to deal with the $A$ of Time during the process of English-Vietnamese translation:

Tip 1: Apply frequently in the Vietnamese clause the range topic of Time as well as the double Topic, the first Topic being Time; pay enough attention to the Vietnamese final sequence of two adverbials, the second adverbial being Time.

Tip 2: Do not change the Topic-Comment structure when translating from English to Vietnamese, as in (29-32)a-b, if there is no compelling reason:

(29)a. Tonight I'll call you.

b. Tối nay tôi sẽ gọi cho chị.

(30)a. After summer comes autumn.

b. Hết hè thì thu tới.

(31)a. After a storm comes a calm.

b. Sau cơn dông là lúc trời yên, biển lặng.

(32)a. I like to sleep until noon, and sometimes I sleep later.

b. Tôi thích ngủ đến tận 12 giờ trưa, và đôi khi tôi còn ngủ trễ hơn.

This tip works even when there are two or more adverbials, including an $A$ of Time, in the English clause in which the cooccurrence of an adverbial of Frequency (abbreviated to $A$ of Frequency) (Quirk et al, 1985, p. 482) [6] and an $A$ of Time is observed in (33)a-b:

(33)a. In the United States there is usually no school on weekends.

b. Ở Mỹ thuờng không có lớp học vào ngày nghi cuối tuần.

Tip 3: Try to distinguish the role of the $A$ of Time from that of the range topic of Time, which may lead Vietnamese language users to the risk of mistakenly translating the English clause with the A of Time. According to Dyvik (1984, p. 10) [4], since "fronting of constituents is a way of topicalization" in the English language, every day, as the range topic of Time in (34)a, brings to the sentence a 
meaning that is quite different from that of (35)a with every day playing the role of the $A$ of Frequency at the end of the clause in question:

(34)a. Every day five thousand people pass through that door.

b. Mỗi ngày năm nghìn người đi qua cánh cửa đó.

(35)a. Five thousand people pass through that door every day.

b. Năm nghìn người đi qua cánh cửa đó mối ngày.

In Dyvik's explanation, (34)a simply indicates the number of persons who pass through that door every day without implying, like (35)a, that the act of passing through that door is performed by the same five thousand people. This is because, as the range topic of Time, every day does not mark five thousand people in (34)a as "the given information." Thus in Dyvik's belief, the English language, like the Vietnamese language, does distinguish the range topic of Time in (34)a from the $A$ of Time in (35)a, due to their different functions to convey meaning. Unfortunately, Dyvik's assertion is still far from convincing: Are (35)a and the following (36)a synonymous (Thanh M. To, 2011, p. 285286) [8]?

(36)a. The same five thousand people pass through that door every day.

b. Cùng năm nghìn người ấy đi qua cánh cửa đó mô̂i ngày.

\subsection{Cases of Fronting the English A of Time and their Potential Change in Meaning}

In order to find out satisfactory answers to the issue regarding the fronting of the English $A$ of Time, as in (29)a and (34)a, and the difference in meaning that the two sentences may have as compared respectively to that of (1)a and (35)a, I have tried my best to contact a number of friends and colleagues ${ }^{7}$ whose mother tongue is English to ask for their personal opinions on which the following generalization is based:

4.4.1. In general, the unmarked position for the time expression is at the end; therefore, the fronting of the $A$ of Time would be rather less common. The main difference would depend on topic emphasis. For example, each of the following pairs of sentences conveys basically the same message, but maybe there is a subtle shade of difference in meaning when the fronting of the A of Time is applied:

- The emphasis in (29)a is on when the call will be made; as for (1)a, the emphasis is on the action of calling as well as who will be calling;

- The emphasis in (35)a is on the number of people, as for (34)a, the emphasis is on the repetitive or ongoing nature of the activity.

Such different shades of meaning are still correct in (3738)a, with the existence of another time reference since then what is stated in the main clause holds true:

(37)a. Every day since the building opened in 2002 five thousand people have passed through that door.

${ }^{7}$ who wish to remain anonymous in this paper b. Mối ngày tù khi tòa nhà đi vào hoạt động năm 2002 năm nghìn người đi qua cánh cửa đó.

(38)a. Five thousand people have passed through that door every day since the building opened in 2002.

b. Năm nghìn người đi qua cánh cửa đó mối ngày tù khi tòa nhà đi vào hoạt động năm 2002.

4.4.2. More specifically, sentences beginning with the time expression would be used in formal situations and thus are not very common; they have much more impact than those with an $A$ of Time at the end. An example is the famous message sent to American paratroopers on the eve of D-Day ${ }^{8}$ : 'Tonight is the night of nights.' This is part of an announcement made to an audience, to add emphasis and importance to the time being mentioned and to the announcement itself. In everyday speech, the sentences beginning with a time expression might also be used to place emphasis on the time so that it is not forgotten:

Dialogue 6:

Jack: We're going fishing on Wednesday and hunting on Thursday, right?

(Jack: Bọn mình sẽ đi câu vào ngày thứ Tu và đi săn vào ngày thư Năm, đúng không?)

Kevin: No, Wednesday is hunting and Thursday is fishing. (Kevin: Không, thứ Tư (thì) đi săn còn thứ Năm (mới) đi câu.)

But this is a flexible rule: it is just as acceptable for Kevin to say 'No, hunting is on Wednesday and fishing is on Thursday.' And this is a fairly common use of the item.

4.4.3. As for when native speakers of English apply the fronting of the A of Time, it is more common to use fronting with the $A$ of Frequency (every day, each morning, sometimes, most Saturdays, etc.), whereas fronting with the $A$ of Point of Time or the A of Extent in Time (tonight, tomorrow, yesterday, on Saturday, etc.) seems a bit less common. Therefore, (34)a sounds completely natural to native speakers of English, whereas the speakers would not use (29)a unless they really emphasized when they were going to call, or wanted to make a contrast (e.g. 'I usually forget to call, but tonight I'll (definitely) call you', or 'Most nights I call Sandra, but tonight I'll call you').

4.4.4. It is interesting to come up with the fact that native speakers' perceptions through feeling on possible change of meaning when the fronting of the English $A$ of Time is applied are not exactly the same. Below is a personal opinion:

"There is a full semantic range in syntax as well as lexicography to be considered in order to distinguish the meanings of the three sentences numbered (34-36)a: (35)a does not exclude the possibility of referring to the same group of people carrying out the daily habitual action; it is more suggestive of the situation described in (36)a than (34)a is, but is by no means confined to it; likewise, while (34)a is less suggestive of the situation in (36)a than (35)a, neither is it exclusive of it.

${ }^{8}$ This was June 6, 1944 when during World War II, the allies landed in France to begin the spread of their forces through Europe, under the command of General Eisenhower to liberate Europe from the atrocities of Hitler. 
This semantic range is useful to accommodate any ambiguity on the part of the writer/ speaker, but the grammatical tools are not required and native speakers of English can use (34)a and (35)a in free variation. Only (36)a is bound to the 5000 people being identical as opposed to a different set of 5000 people on any given day."

And here is another personal opinion, stating that neither (35)a is more nor (34)a is less suggestive of the situation described in (36)a and that while it is possible for (35)a not to exclude the possibility of referring to the same group of people carrying out the daily habitual action, it is certainly not clear that the speaker is mentioning the same five thousand people.

It's time to come to the conclusion that, unlike Vietnamese, English does not distinguish the range topic of Time from the $A$ of Time, for (34)a and (35)a are synonymous to the native speakers of English who have been involved in the research reported in this paper, expressing their disagreement with Dyvik's belief. Also to all of them, (36)a is more specific than the other two because of the word same.

\section{Conclusion}

There are few situations where English sentences would begin with a time expression, i.e. the fronting of the $A$ of Time is marked in the English clause. It is topic emphasis that determines the choice concerning the position of the $A$ of Time: at the beginning of the English clause if the focus is the time being mentioned; at the end of the English clause if the interlocutor would like to focus on the action itself and/ or the person (s) who do(es) it. Since the unmarked position for the time expression is at the end, English sentences beginning with a time expression would be used in formal situations and thus are not very common. In everyday speech, however, native speakers of English may flexibly apply the fronting of the $A$ of Time or not because both are just acceptable, with basically the same message added by a subtle shade of difference in the meaning being conveyed.

The range topic of Time is so common at the beginning of the Vietnamese clause that this case is definitely unmarked in Vietnamese. That is the reason why during the process of English-Vietnamese translation, the $A$ of Time is almost obligatorily fronted usually from the end of an English clause to the beginning of its Vietnamese version, following the Topic-Comment structure prominently observed in the Vietnamese clause. Such fronting is not obligatory but optional in a number of cases:
- When the translated version has its final $A$ of Time in the form of not an NP but a PP so that the principle of end-weight may be obeyed strictly;

- When there exists a final sequence of an A of Space before an $A$ of Time, which is quite common in the two languages in question;

- When the English clause has its final $A$ of Time referring not to Point ot Time but to Extent in Time.

Hopefully, what has been presented draws attention of those who are involved in English-Vietnamese translation to such a delicate choice of either maintaining the $A$ of Time at the end or converting it into the range topic of Time at the beginning of the translated version. There is no doubt that such a choice, however small it is, plays a meaningful role in language learning in general, in the practice of translation in particular.

\section{References}

[1] Stageberg, N. C. and Oaks, D. D. (2000) An Introductory English Grammar. Fifth Edition. Fort Worth, TX: Harcourt College Publishers.

[2] Cao. X. H. (1991) Tiếng Việt - Sơ thảo ngữ pháp chức năng (The Vietnamese Language - A Rough Draft on Functional Grammar), Hanoi: Publishing House of Social Sciences.

[3] Halliday, M. A. K. (1994) An Introduction to Functional Grammar, Second Edition, London: Arnold.

[4] Dyvik, H. J. J. (1984) Subject or Topic in Vietnamese, University of Bergen, Norway (provided in the form of a typed material in 1994 to Department of Vietnamese Literature and Linguistics, Ho Chi Minh City University of Pedagogy by Mr. Olaf Husby).

[5] Hurford, J. R., Heasley, B. and Smith, M. B. (2007) Semantics - A Course Book. Cambridge: Cambridge University Press.

[6] Quirk, R.; Greenbaum, S; Leech, G.; and Svartvik, J. (1985) A Comprehensive Grammar of the English Language, London and New York: Longman Group Ltd.

[7] Biber, D.; Johansson, S.; Leech, G.; Conrad, S.; and Finegan, E. (1999) Longman Grammar of Spoken and Written English, London: Pearson Education Ltd.

[8] To. M. T. (2011) Vai nghĩa trong câu trần thuật tiếng Việt và tiếng Anh (Semantic Roles in Vietnamese and English Declaratives), Ho Chi Minh City: Publishing House of Vietnam National University - Ho Chi Minh City.

[9] Cook, G. (1989) Discourse, Oxford: Oxford University Press. 